\title{
Cutaneous Leiomyomatosis - Case Report and Literature Review
}

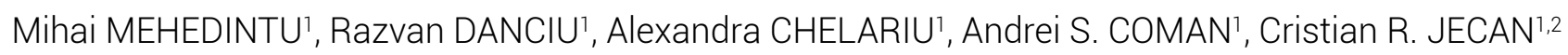

\begin{abstract}
Cutaneous leiomyomas are uncommon benign smooth muscle tumors that comprise of three distinct types such as piloleiomyoma, angioleiomyoma, and genital leiomyoma. The discovery in 2001 of the association between cutaneous leiomyomas, uterine leiomyomas in women, and an aggressive form of renal cell cancer (RCC) underscores the importance of accurate dermatologic diagnosis of $\mathrm{CL}$ so that appropriate cancer screening and counseling of patients and at-risk relatives can be instituted. The present case report will discuss the pathogenesis, clinical manifestations, diagnosis, and management of a piloleiomyoma.
\end{abstract}

Keywords: Cutaneous leiomyomas, piloleiomyoma.

\section{Rezumat}

Leiomiomele cutanate sunt tumori benigne mai puțin frecvente ale mușchilor netezi, care cuprind trei tipuri distincte, cum ar fi ca piloleiomiom, angioleiomiom și leiomiom genital. Descoperirea în 2001 a asocierii dintre leiomioame cutanate, leiomioame uterine la femei și o formă agresivă de cancer cu celule renale (CCR)cresc importanța diagnosticului dermatologic precis al acestor forme de tumori, astfel încât screeningul și consilierea adecvată a pacientilor cu astfel de neoplazii și rude cu risc pot fi instituite. Prezentul raport de caz va discuta patogeneza, clinică manifestări, diagnostic și gestionarea unui piloleiomiom.

Cuvinte cheie: leiomioame cutanate, piloleiomiom.

\section{SUMMARY}

The present case is that of a 36-year-old male, with a known history of piloleiomyoma. He underwent a first treatment attempt in 2010, in the form of excision and skin grafting of tumors located in the left pectoral/ deltoid region. Since then, new tumors have developed distally to the previous ones, affecting the upper left limb almost entirely, with only the skin of the hand being left unaffected, both dorsally and volarly. It is important to mention that the region of the previous skin graft had remained also unaffected, with neither symptoms, nor visible tumors.

\section{INTRODUCTION}

Cutaneous leiomyomas, also called piloleiomyomas, are uncommon smooth muscle tumors that are benign and derive from the muscles responsible for piloerection of hair follicles, the arrector pili muscles ${ }^{1}$. When $\mathrm{Cu}^{-}$ taneous leiomyomas occur in multiple numbers, they are most likely part of a cancer syndrome abbreviated
1 Department of Plastic and Reconstructive Surgery, "Prof. Dr. Agrippa Ionescu" Emergency Clinical Hospital, Bucharest, Romania

2 Department of Plastic and Reconstructive Surgery, "Carol Davila" University of Medicine and Pharmacy, Bucharest, Romania
Corresponding author.

Mihai MEHEDINTU, Department of Plastic and Reconstructive Surgery, „Prof. Dr. Agrippa Ionescu” Emergency Clinical Hospital, Bucharest, Romania.

E-mail: drmehedintu@gmail.com 


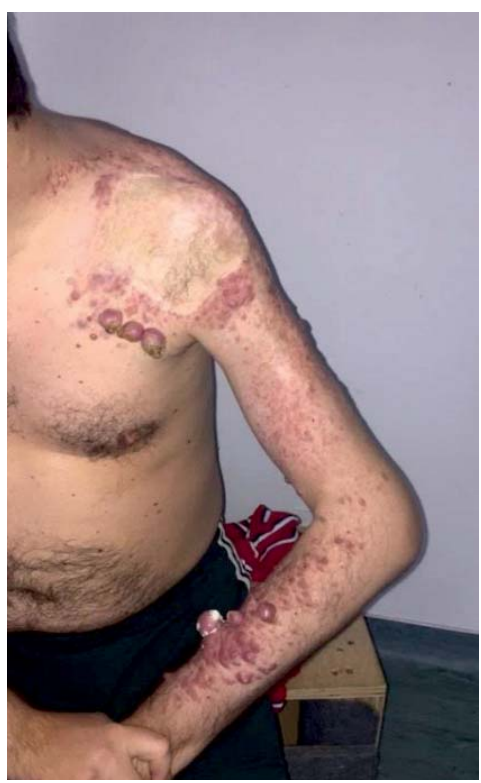

Figure 1.

HLRCC, which stands for hereditary leiomyomatosis and renal cell cancer; this is an autosomal dominant cancer syndrome ${ }^{2}$.

The discovery in 2001 of the relation between an aggressive form of renal cell cancer (RCC), uterine leiomyomas in women and cutaneous leiomyomas underscores how important it is to accurately diagnose cutaneous leiomyomas so that appropriate cancer screening and counseling of patients and at-risk relatives can be instituted ${ }^{3}$.

Leiomyomas are painful in the majority of cases, with pain being most often either unprompted or triggered by a certain stimulus (physical and/or emo-

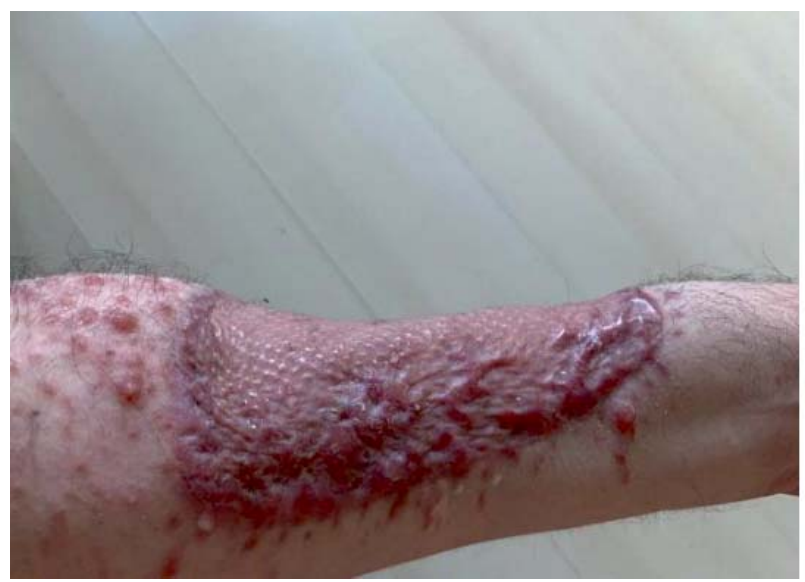

Figure 2. tional, cold temperature or pressure); possible triggers may also include menses or pregnancy ${ }^{1}$.

\section{CASE REPORT}

Our patient was a 36-year-old male presenting with piloleiomyoma for approximately 15 years. He had undergone a surgical treatment in 2010, where the affected area of skin, which was at the time limited to the left pectoral and deltoid region, was excised and primarily skin grafted. The patient was now readmitted due to the progression of the tumors, with some adjacent to the skin graft, distally but with most of them encompassing the whole left upper limb (except for the left hand).

On clinical examination were identified multiple pink nodules ranging in size between $1 \mathrm{~cm}$ and $3 \mathrm{~cm}$ in diameter, on the dorsal side of the left upper limb from the radiocarpal joint to the level of the scapulohumeral joint, which infiltrate the dermis and are extremely painful to the touch (Figure 1). The patient also has painful episodes accompanied by sweating and anxiety that are slowly ameliorated by calcium-blocking medication.

Paraclinical evaluation showed normal blood tests, EKG showed sinus rhythm without signs of heart blocks or any other abnormalities and the heart rate was about 70 beats per minute. Thoracic radiographs showed free costophrenic sinuses, and no pleuropulmonary evolutionary lesions; heart and aorta were within normal limits; nodular opacities projected at soft parts in the left axillary region with maximum dimensions of $32 / 24 \mathrm{~mm}$.

Surgical intervention: the nodular formations on the dorsal side of the left forearm were resected "en bloc",

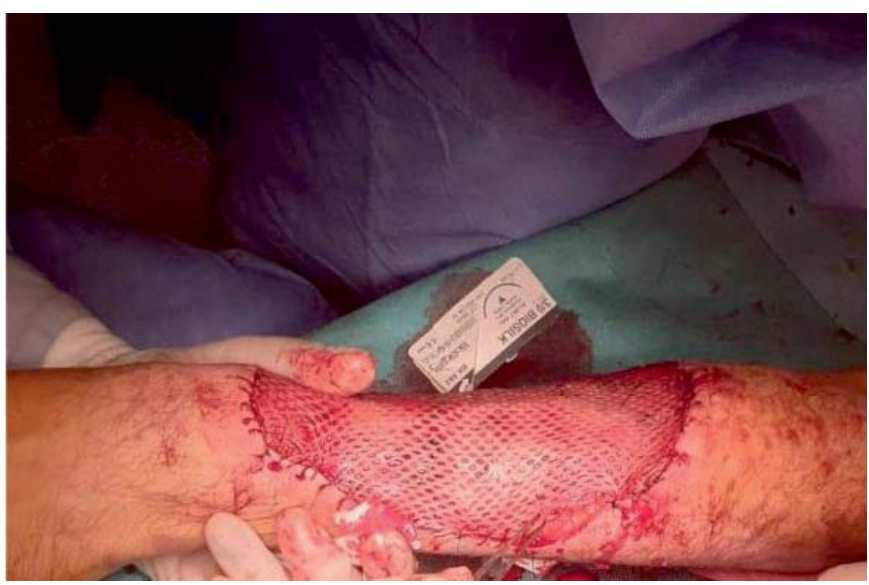

Figure 3. 


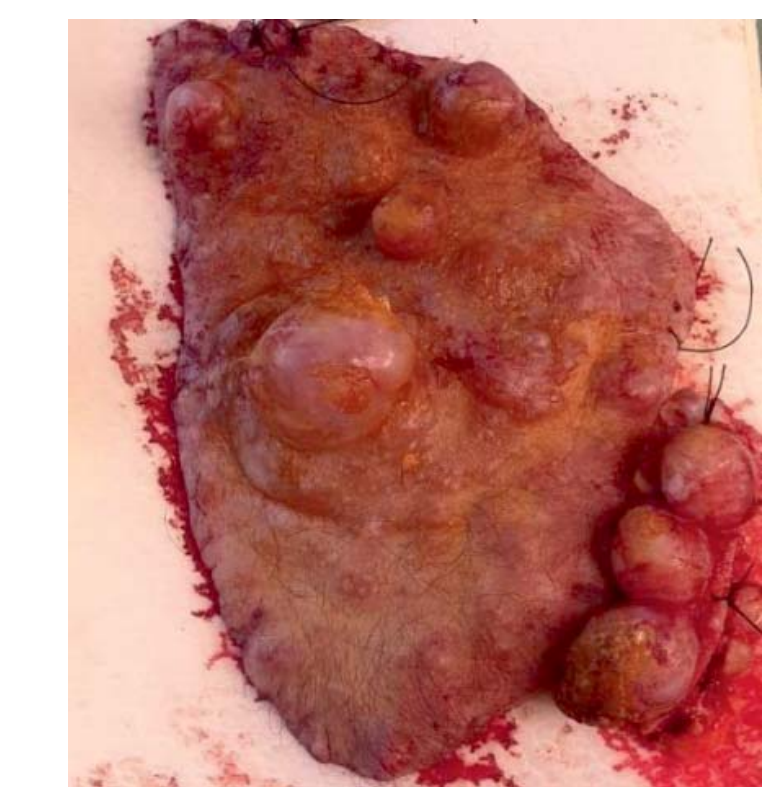

Figure 4.

down to the deep dermis, and the remaining defect $(15 / 6 \mathrm{~cm})$ was covered with a $0.5 \mathrm{~mm}$ thick skin graft, expanded by 1:1.5 (Figure 2 and 3). The skin formations from the left distal deltopectoral space were also resected "en bloc", resulting in a smaller defect $(6 / 2$ $\mathrm{cm}$ ), which was easily closed primarily, while the medial left arm skin formations were individually excised, but also closed primarily.

The histopathological examination revealed multiple firm, pinkish tumors, with diameters ranging from 0.2 $\mathrm{cm}$ to $5 \mathrm{~cm}$, all with regular edges (Figure 4).

The microscopic examination revealed the proliferation of elongated cells, presenting a low degree of histological aggressiveness, which suggested a leiomyoma. As an immunohistochemical evaluation, the streptavidin-biotin/horseradish peroxidase complex method was used to detect antigens such as desmin, S100, SMA (smooth muscle actin) and CD34. The tumor cells were slightly positive for desmin and SMA stains, but negative for S100 and CD34. The histological pattern corresponded to a cutaneous leiomyoma with a very high probability of hereditary leiomyomatosis and renal cell cancer syndrome (HLRCC).

The patient's evolution is favorable, at 7 days postoperatively the graft is integrated and the patient is discharged.

\section{DISCUSSIONS}

Cutaneous leiomyomas was first described in the literature by Rudolf Virchow in $1854^{4}$. These are rare ben- ign tumors of smooth muscle cells that can be classified into 3 types depending on the place of origin. Piloleiomyomas are benign formations that arise from the arrector pilli muscles, angioleiomyomas are formations that derive from smooth muscles within the vascular walls and dartoic leiomyomas are formations that originate in the smooth muscles of the genital skin. Of these, the most common form is Piloleiomyoma ${ }^{5}$.

Approximately $75 \%$ of all extra-uterine leiomyomas are represented by Cutaneous leiomyomas. Their incidence does not appear to be related to race ${ }^{6}$. Solitary cutaneous leiomyomas typically occur in the lower extremities, and mostly in adulthood, whereas multiple piloleiomyomas tend to occur anywhere on the body, with various distribution patterns and most commonly between the ages of 10 and 30 years $^{7}$.

When autosomal dominant syndromes are excluded, the incidence of piloleiomyoma appears to be equal in women and men, compared to angioleiomyomas, which are statistically more common in women than men $(2: 1)$. The exception to this is represented by the cavernous and venous subtypes; they are more common in men $^{8}$.

Clinically patients present with skin formations having the appearance of red or brown nodules or papules located mainly on the limbs and trunk. These benign tumors respond by pain to pressure and low temperatures, but multiple painful episodes are described without an illusory cause that requires medication to release it ${ }^{10}$. The incriminated physiological mechanism is not completely elucidated, but there are multiple theories that justify the appearance of pain. Theories that have been proposed: the contraction of smooth muscle fibers, the invasion of cutaneous nerve threads or numerous nerve elements located inside the formations ${ }^{4,11}$.

The evolution and extent of the lesions are variable even within the same family. Their size and number are gradually increasing, but without a constant rate. In some cases, patients suffer from an extensive disease with lesions covering large areas of the body and others have only a few imperceptible papules ${ }^{12}$.

The histopathological examination represents the diagnosis of choice; it shows a tumor with poorly differentiated dermal structure, composed of spindle cells woven with collagen fibers. Immunohistological staining is positive for anti- $\alpha$-smooth muscle desmin and actin. In addition, there are many atypical cells present in different mitotic stages 9 .

The treatment of piloleiomyoma is individualized and is based on the patient's symptomatology. A good 
therapeutic option may be the excision of the reduced formations that cause pain or unsightly appearance. Their excision often determines the remission of symptoms ${ }^{13}$. Closing the remaining skin defects can be done by direct closure, using split free skin grafts or local or remote flaps. It should be borne in mind that recurrences may occur at this level. Extended cases with severe symptoms are more difficult to manage and total remission is difficult to obtain, so adjuvant drug treatments have been proposed such as: calcium channel blockers such as Nifedipine, they prevent the influx of calcium into the smooth muscles; alpha-adrenergic blockers such as Doxazosin or antiepileptics such as Gabapentin, having fewer side effects and being better tolerated by patients ${ }^{14,15}$. It should be noted that oral medication should be gradually reduced after surgery because patients may have painful complaints even after surgical excision. Other alternative studied therapies were $\mathrm{CO}_{2}$ laser therapy which seems to show an improvement in patients' symptoms, but cryotherapy and electrocoagulation appear to be ineffective ${ }^{16}$.

In the long term, recurrences have been found to be common, especially in patients with extensive lesions. For this reason, it is necessary to follow up with clinical

\section{References}

1. Raj S, Calonje E, Kraus M, et al. Cutaneous pilar leiomyoma: clinicopathologic analysis of 53 lesions in 45 patients. Am J Dermatopathol 1997; 19:2.

2. Schmidt LS, Linehan WM. Hereditary leiomyomatosis and renal cell carcinoma. Int J Nephrol Renovasc Dis 2014; 7:253.

3. Menko FH, Maher ER, Schmidt LS, et al. Hereditary leiomyomatosis and renal cell cancer (HLRCC): renal cancer risk, surveillance and treatment. Fam Cancer 2014; 13:637.

4. Virchow R. Ueber carvernose (erectile) geschwulste und teleangiektasien. Arch Pathol Anat Physiol Klin Med 1854;6:525-54.

5. Fischer Z, Helwig E. Leiomyomas of the skin. Arch Dermatol 1963; 88: 510-20.

6. Kudur $\mathrm{MH}$. A generalized multiple cutaneous piloleiomyomatosis in a young male: Rare case report. Indian journal of dermatology. 2013 May;58(3):245

7. Holst VA, Junkins-Hopkins JM, Elenitsas R. Cutaneous smooth muscle neoplasms: clinical features, histologic findings, and treatment options. J Am Acad Dermatol. 2002 Apr. 46(4):47790; quiz, 491-4.

8. Ramesh P, Annapureddy SR, Khan F, Sutaria PD. Angioleiomyoma: a clinical, pathological and radiological review. Int J Clin Pract. 2004 Jun. 58(6):587-91 and imaging examinations throughout life. Also, these examinations have the role of early detection of a renal tumor formation being known the association of these two diseases (risk of $10-16 \%)^{2}$.

\section{CONCLUSIONS}

Cutaneous leiomyomas are a rare condition that can be associated with other systemic manifestations and has clinical diagnostic difficulties due to the unusual form of presentation. The patient's health is severely affected due to sporadic pain.

The treatment of choice that improves the patient's quality of life is the surgical operation associated with calcium-blocking and alpha-blocking drug therapy. Recurrences are common, these patients require monitoring for the rest of their lives.

Compliance with ethics requirements: The authors declare no conflict of interest regarding this article. The authors declare that all the procedures and experiments of this study respect the ethical standards in the Helsinki Declaration of 1975, as revised in 2008(5), as well as the national law. Informed consent was obtained from all the patients included in the study.

9. Holst VA, Junkins-Hopkins JM, Elenitsas R. Cutaneous smooth muscle neoplasms: clinical features, histologic findings, and treatment options. J Am Acad Dermatol 2002; 46: 477-90.

10. Archer $\mathrm{CB}$, Greaves MW. Assessment of treatment for painful cutaneous leiomyomas. J Am Acad Dermatol 1987; 17: 141-2.

11. Thyresson HN, Su WP. Familial cutaneous leiomyomatosis. J Am Acad Dermatol 1981; 4: 430-4.

12. Mann PR. Leiomyoma cutis: an electron microscope study. $\mathrm{Br} \mathrm{J}$ Dermatol 1970; 82: 463-9.

13. Kudur $\mathrm{MH}$. A generalized multiple cutaneous piloleiomyomatosis in a young male: Rare case report. Indian J Dermatol. 2013;58:245.

14. Chaves AJ, Fernández-Recio JM, de Argila D, Rodríguez-Nevado I, Catalina M. Zosteriform Cutaneous Leiomyoma. Satisfactory Treatment With Oral Doxazosin. Actas Dermosifiliogr. 2007;98:494-6

15. Alam $M$, Rabinowitz $A D$, Engler DE. Gabapentin treatment of multiple piloleiomyoma-related pain. J Am Acad Dermatol. 2002;46:S27-9.

16. Christenson LJ, Smith K, Arpey CJ. Treatment of multiple cutaneous leiomyomas with CO2 laser ablation. Dermatol Surg. 2000;26:319-22. 